\title{
PREVALENCE OF ANTIBODIES AGAINST INFLUENZA VIRUS IN NON-VACCINATED EQUINES FROM THE BRAZILIAN PANTANAL
}

Lucas GAÍVA E SILVA(1,2), Alice Mamede Costa Marques BORGES(1), Eliana Monteforte Cassaro VILLALOBOS(3), Maria do Carmo Custodio Souza Hunold LARA(3), Elenice Maria Siquetin CUNHA(3), Anderson Castro Soares de OLIVEIRA(4), Ísis Assis BRAGA(1) \& Daniel Moura AGUIAR(1,5)

\begin{abstract}
SUMMARY
The prevalence of antibodies against Equine Influenza Virus (EIV) was determined in 529 equines living on ranches in the municipality of Poconé, Pantanal area of Brazil, by means of the hemagglutination inhibition test, using subtype H3N8 as antigen. The distribution and possible association among positive animal and ranches were evaluated by the chi-square test, spatial autoregressive and multiple linear regression models. The prevalence of antibodies against EIV was estimated at 45.2\% (95\% CI 30.2 - 61.1\%) with titers ranging from 20 to 1,280 HAU. Seropositive equines were found on $92.0 \%$ of the surveyed ranches. Equine from non-flooded ranches $(66.5 \%)$ and negativity in equine infectious anemia virus (EIAV) $(61.7 \%)$ were associated with antibodies against EIV. No spatial correlation was found among the ranches, but the ones located in non-flooded areas were associated with antibodies against EIV. A negative correlation was found between the prevalence of antibodies against EIV and the presence of EIAV positive animals on the ranches. The high prevalence of antibodies against EIV detected in this study suggests that the virus is circulating among the animals, and this statistical analysis indicates that the movement and aggregation of animals are factors associated to the transmission of the virus in the region.
\end{abstract}

KEYWORDS: Equine; Influenza virus; Pantanal; Brazil; Prevalence.

\section{INTRODUCTION}

Brazil is home to the world's third largest horse herd, with 5.9 million animals, second only to China and Mexico. The Brazilian equine industry is an important segment of agribusiness, employing over one million people in over 120 activities that range from saddle manufacturing to equestrian tourism ${ }^{6}$.

In some specific situations horses are indispensable for ranch work, especially in regions like the Pantanal in the state of Mato Grosso, which are flooded during certain periods of the year, leaving horses as the sole feasible mode of transport ${ }^{16}$. In such conditions, the occurrence of some diseases can directly impact horse breeding on ranches, especially diseases with high morbidity, such as that caused by the equine influenza virus (EIV). Equine influenza occurs worldwide and is characterized by respiratory syndromes that affect equines. Farmers recognize it as a highly contagious disease whose symptoms are fever, depression, nasal discharge, and hence, diminished physical performance ${ }^{18}$.

EIV belongs to the Orthomyxoviridae family, and the genus Influenza A has a segmented negative-strand RNA genome. EIVs are classified based on the number of hemagglutinin and neuraminidase glycoproteins present in the viral envelope. According to this classification, two EIV subtypes are known to be responsible for infection in equines: A/equi/1 (H7N7) and A/equi/2 (H3N8) ${ }^{11}$. Cases of equine influenza caused by subtype H7N7 have not been diagnosed since the 80s. However, subtype $\mathrm{H} 3 \mathrm{~N} 8$ has been reported in several cases of epizootic respiratory disease around the world ${ }^{18}$.

Due to the importance of equine influenza, this study proposes to estimate the seroprevalence of the equine influenza virus in a nonvaccinated equine population in the municipality of Poconé, state of Mato Grosso, which is a considerably large region of the Brazilian Pantanal. Epidemiological information about the infection in this environment was based on the serological results of this survey.

\section{MATERIAL AND METHODS}

Study area: The municipality of Poconé is located in the northeastern area of the Pantanal wetlands $\left(16^{\circ} 15^{\prime} 24^{\prime \prime} \mathrm{S}, 56^{\circ} 37^{\prime} 22^{\prime \prime} \mathrm{W}\right), 100 \mathrm{~km}$ southwest of the city of Cuiabá, the capital of the state of Mato Grosso. The municipality has a population of approximately 19,800 equines distributed among 700 ranches, according to the 2009 census $^{10}$. These ranches cover an area of 17,261.1 $\mathrm{km}^{2}, 81 \%\left(\sim 14,000 \mathrm{~km}^{2}\right)$ of which

(1) Programa de Pós-graduação em Ciências Veterinárias, Universidade Federal de Mato Grosso, Cuiabá, MT, Brazil.

(2) Associação Brasileira de Criadores do Cavalo Pantaneiro, Poconé, MT, Brazil

(3) Laboratório de Raiva e Encefalites Virais, Instituto Biológico, São Paulo, SP, Brazil.

(4) Departamento de Estatística, Universidade Federal de Mato Grosso, Cuiabá, MT, Brazil.

(5) Laboratório de Virologia e Rickettsioses, Hospital Veterinário da Universidade Federal de Mato Grosso, Cuiabá, MT, Brazil.

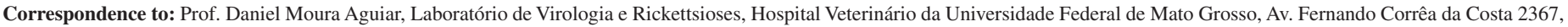
Bairro Boa Esperança, 78060-900 Cuiabá, MT, Brasil. E-mail: danmoura@ufmt.br 


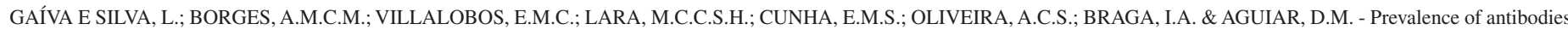
against influenza virus in non-vaccinated equines from the Brazilian Pantanal. Rev. Inst. Med. Trop. Sao Paulo, 56(6): 487-92, 2014.

are flooded each year during the rainy season ${ }^{10}$. The area is located at an altitude of $142 \mathrm{~m}$ above sea level; its climate is hot and rainy in spring and summer, with mean temperatures of about $32^{\circ} \mathrm{C}$, and cool and dry in autumn and winter months, when the mean temperature is approximately $21^{\circ} \mathrm{C}$.

Equine samples: The equine population under analysis was that described in the study of BORGES et al. ${ }^{4}$ regarding Equine Infectious Anemia (EIA). The samples were estimated based on conglomerate sampling ${ }^{3}$, using an estimated prevalence of $18 \%{ }^{17}, 10 \%$ error and $99 \%$ confidence interval. The number of visited clusters (cattle ranches) was calculated using C Survey software ${ }^{2}$. From this estimate, 25 properties were selected randomly among the ranches registered at the Instituto de Defesa Agropecuária (INDEA) of Mato Grosso, involving a total of 489 horses and 40 mules (Equus asinus $\times$ Equus caballus). Blood samples were collected between January and July 2010 by jugular venipuncture, using $21 \mathrm{G}$ needles suitable for vacuum tubes. At the time of blood sampling, a questionnaire about health variables was applied covering the animal's zoo technical data, the type of management adopted on the ranch, and measures were employed to prevent infectious diseases. This data was fed into a database created using Microsoft Excel. The blood sampling procedures were approved by the Bioethics Committee on Animal Research of the Federal University of Mato Grosso - UFMT, under Protocol no. 23108.026941/12-1.

Serological analysis: Antibodies against EIV were detected by Hemagglutination Inhibition assay (HI) according to procedures recommended by the World Organization for Animal Health ${ }^{12}$. Serum samples were previously treated by inactivation in a dry ice water bath at $56^{\circ} \mathrm{C}$ for 30 minutes, followed by washing with $25 \%$ Kaolin solutions and chicken erythrocyte treated solution at $50 \%(\mathrm{v} / \mathrm{v})$. The sera were tested against the viral subtype of Influenza A Eq2 (strain SP/1/85), starting from four hemagglutinating units (4 HAU) and $0.5 \%$ of chicken erythrocyte solution. Samples showing antibody titers of 20 HAU were considered positive and the final titer was the reciprocal of the highest dilution capable of inhibiting the hemagglutinating effect.

Statistical Analysis: Prevalence values were calculated separately for individual animals and ranches (herds). Because ranches with different herd sizes were evaluated, the estimate of apparent prevalence was adjusted based on the herd size of each surveyed ranch, according to Formula (1).

Formula (1):

Weight $=\frac{\text { no. equines on the ranch }}{\text { no. of sampled equines }} \times \frac{\text { no. of equines in the municipality }}{\text { no. of equines on all sampled ranches }}$

The apparent prevalence, standard error, $95 \%$ confidence interval and design effect were calculated by means of the Complex Sample Analysis application of SPSS 16.0 for Windows. The intracluster correlation coefficient $(\rho)$ was determined using Formula $(2)^{14}$, where $\mathrm{X} n$ is the average herd size.

Formula (2):

$$
p=\frac{\text { Design effect }-1}{\mathrm{X}_{\mathrm{n}}-1}
$$

The association between positivity to antibodies against EIV and independent variables was analyzed considering herd size values adjusted by the chi-square $\left(\chi^{2}\right)$ or Fisher's exact test, and $p \leq 0.05$ was considered significant. The statistical software SPSS version 16.0 for Windows was used for this analysis.

The Spatial Lag Model (Spatial AutoRegressive - SAR) was employed as described by CÂMARA et al. ${ }^{5}$, using Formula (3), where Y is the dependent variable considered as the prevalence of positive animals per ranch, W is the spatial proximity matrix, WY expresses a spatially lagged dependent variable for $\mathrm{Y}, \mathrm{X}$ signifies the explanatory variables, $\varepsilon$ is a vector of error terms, $\rho$ is the spatial autoregressive coefficient, and $\beta$ represents the regression coefficients of variables.

Formula (3):

$$
Y=\rho W Y+X \beta+\varepsilon
$$

The analyzed variables were: Animal Density (D), Equine Function (F), EIAV Control (C), Location of Ranches (L), and Prevalence of EIAV by ranch (PA). The first model tested was represented by Formula (4). The value of $\mathrm{W}$ was obtained considering all the ranches as neighbors, since their borders could not be determined, and the weight of the neighborhood as the inverse of the distance between ranches as their geographical coordinates. To obtain a summarized model considering only significant variables, each variable was tested combined (multivariate) and individually (univariate).

Formula (4):

$$
Y=\rho W Y+\beta 0+\beta 1 D+\beta 2 F+\beta 3 C+\beta 4 L+\beta 5 P A
$$

Additionally, a multiple linear regression model was applied to evaluate possible risk factors related to positivity between properties. The model was created using Formula (5), according to CÂMARA et al. ${ }^{5}$; $Y$ represents the dependent variable prevalence of positive animals per ranch, $X$ represents the independent variables, $\beta$ the regression coefficient of covariates, and $\varepsilon$ the random error with mean zero and variance $\sigma^{2}$.

Formula (5):

$$
\mathrm{Y}=\mathrm{X} \beta+\varepsilon
$$

The analyzed variables were: Animal Density (D), Equine Function (F), EIAV Control (C), Location of Ranches (L), and Prevalence of EIAV (PA). Thus, the initial model tested was represented by Formula (6). Each covariate was tested individually (univariate) and combined (multivariate) with the other in order to obtain a summarized model considering only the significant covariates.

Formula (6):

$$
Y=\beta 0+\beta_{1} D+\beta_{2} F+\beta_{3} C+\beta_{4} L+\beta_{5} P A
$$

\section{RESULTS}

Of the 25 ranches surveyed in this study, 11 (44.0\%) were located in non-flooded areas and $14(56.0 \%)$ in regularly flooded areas (Fig. 1). The 


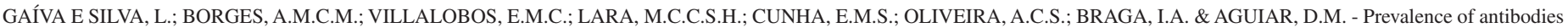
against influenza virus in non-vaccinated equines from the Brazilian Pantanal. Rev. Inst. Med. Trop. Sao Paulo, 56(6): 487-92, 2014.

equine populations on these ranches ranged from 25 to 200 animals, and blood was collected from an average of 21 animals per ranch. Twenty $(80.0 \%)$ of these ranches used the animals exclusively for work, while five $(20.0 \%)$ of them bred equines for events such as agricultural fairs and sports practices (team penning). None of these ranches had adopted EIV vaccination in the preceding period of sampling.

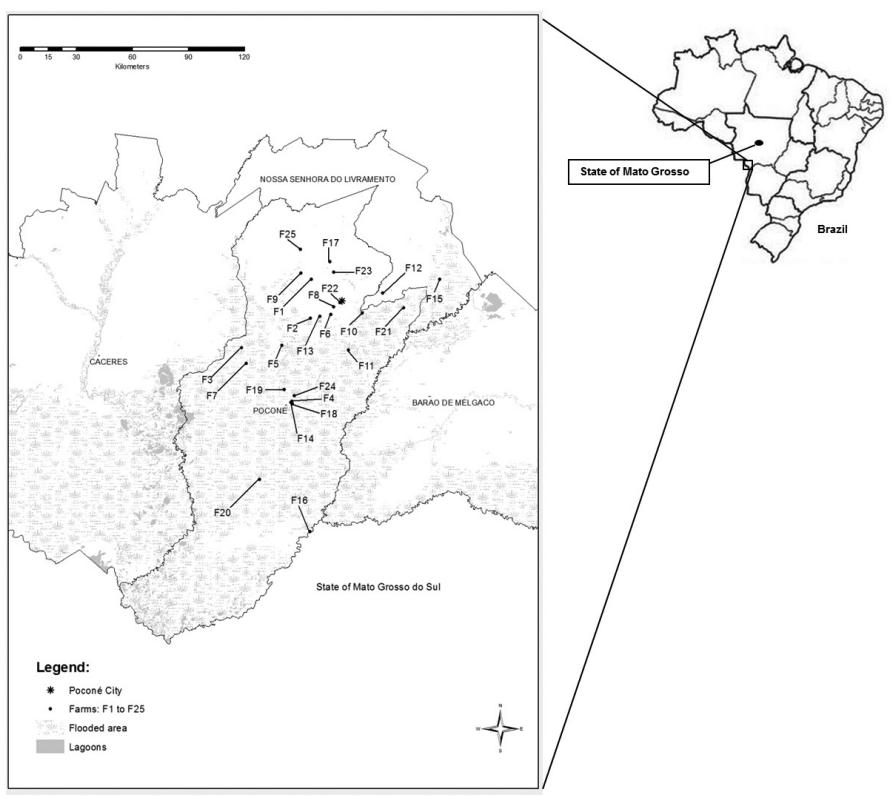

Fig. 1 - Cattle ranches involved in the study on the prevalence of antibodies against EIV in the municipality of Poconé, MT, Brazil.

Table 1 shows the apparent and true prevalence values for herds and individual animals. Intraherd prevalence rates ranged from $15 \%$ to $100 \%$, with a mean prevalence of $54.0 \%$. As for antibody titers, $07(2.4 \%)$ had titers of 20HAU, $17(6.0 \%)$ had titers of 40HAU, 40 (14.0\%) had titers of $80 \mathrm{HAU}, 55(19.2 \%)$ had titers of 160HAU, $59(20.6 \%)$ had titers of $320 \mathrm{HAU}, 64(22.3 \%)$ had titers of $640 \mathrm{HAU}$, and $40(14.0 \%)$ had titers of $1280 \mathrm{HAU}$.

Table 2 lists the results of the association between seropositive animals and the variables studied here. The evaluation of absolute data demonstrated that the associated variables were: equine species, equines not vaccinated against other infections, farm animals located in nonflooded areas, negative for EIAV, and a population density exceeding 0.086 equines per hectare. According to the adjusted analysis, equines living on cattle ranches located in non-flooded areas and negative for EIAV were associated with EIV seropositivity.
An insignificant value ( $p=0.74$ ) was found, according to the Spatial Lag Model, indicating the absence of a spatial correlation between the surveyed ranches and the prevalence of antibodies against EIV. The variables "location" and "EIAV" prevalence proved significant according to the multiple linear regression model (Table 3). This model showed that the highest proportion of seropositive animals lived in non-flooded areas and that the presence of EIAV positive animals was negatively correlated to the presence of EIV seropositivity on the ranches (Fig. 2).

\section{DISCUSSION}

Despite intense vaccination programs adopted by veterinarians and breeders, equine influenza caused by subtype H3N8 still leads to severe economic losses in several regions around the world. This study, which investigated the seroprevalence of antibodies against subtype H3N8 of Influenza A virus in unvaccinated herds in the municipality of Poconé, MT, detected a high prevalence $(92 \%)$ of positivity. This finding is consistent with those of other studies conducted in Brazil, which found prevalence ranging from 65 to $100 \%$, suggesting widespread infection in the region ${ }^{1,9}$.

A high frequency of positive animals (53.3\%) was also observed, demonstrating the active circulation of the virus in this region of the Pantanal. Reactivity of vaccination was discarded, since none of the surveyed herds had a history of vaccination against influenza virus. The estimated prevalence of antibodies among the animals ranged from 30 to $61 \%(\sim 45.2 \%)$, which is consistent with the results of other studies. PENA et al..$^{15}$ in Northern Brazil, HEINEMANN et al..$^{9}$ in the state of Pará and AGUIAR et al. ${ }^{1}$ in the state of Rondônia observed prevalence ranging from 35 to $76 \%$. Data obtained in other states such as Rio Grande do Sul, Mato Grosso do Sul and Rio de Janeiro were also similar, with values of about $40 \%{ }^{8,13,17}$.

In Brazil, the lowest results were reported by CUNHA et al. ${ }^{7}$ in an equine population in the southeastern São Paulo State. This controversial finding is probably due to the low density of the equine populations living on small ranches. On the other hand, in the present study, seropositivity for EIV can be associated with the movement (participation in exhibitions) and agglomeration of animals, whereas equines in ranches located in non-flooding areas, which have a higher animal density than flooded areas and are controlled for EIAV, presented a higher proportion of positive animals. These results are in agreement with the epidemiological features of equine influenza, for which aggregations of animals are considered a risk factor for infection.

This study confirmed unequivocally that cattle ranches with equines testing negative for EIAV are the ones that participate in agricultural fairs

Table 1

Frequency and adjusted prevalence for the presence of seropositivity to EIV in the municipality of Poconé, MT, Brazil

\begin{tabular}{lcccccccc}
\hline Sample & $\mathrm{n}$ & Pos & $\%$ & Prevalence* $(\%)$ & CI 95\% & SE $(\%)$ & DE & Rho* \\
\hline Herds & 25 & 23 & 92.0 & 92.0 & $74.0-92.0$ & 9.2 & 13.1 & 0.14 \\
Animals & 529 & 282 & 53.3 & 45.2 & $30.2-61.1$ & 7.8 & \\
\hline
\end{tabular}

$\mathrm{n}=$ number tested, Pos = number positive; $*$ calculated according to Formula $(1), \mathrm{CI}=$ Confidence interval, $\mathrm{SE}=$ Standard error; $\mathrm{DE}=\mathrm{Design}$ effect calculated in cluster samples; rho = Intracluster correlation calculated according to Formula (2). 


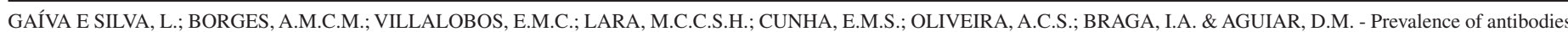
against influenza virus in non-vaccinated equines from the Brazilian Pantanal. Rev. Inst. Med. Trop. Sao Paulo, 56(6): 487-92, 2014.

Table 2

Association found by the Chi-square test between positivity to EIV and independent variables on the cattle ranches surveyed in Poconé, MT, Brazil

\begin{tabular}{|c|c|c|c|c|c|}
\hline \multirow{2}{*}{ Variables } & \multicolumn{2}{|c|}{ Number of equines } & \multicolumn{3}{|c|}{ Chi-square } \\
\hline & Sampled & Positive $(\%)$ & $p$ & $\% *$ & $p^{*}$ \\
\hline \multicolumn{6}{|l|}{ Species } \\
\hline Mule & $40(7.5)$ & $15(37.5)$ & 0.03 & 38.4 & 0.61 \\
\hline Horse & $489(92.5)$ & $267(54.6)$ & & 45.8 & \\
\hline \multicolumn{6}{|l|}{ Sex } \\
\hline Female & $72(13.6)$ & $32(44.4)$ & 0.10 & 43.9 & 0.93 \\
\hline Male & $457(86.3)$ & $250(54.7)$ & & 45.4 & \\
\hline \multicolumn{6}{|c|}{ Vaccine against other infections** } \\
\hline No & $247(46.6)$ & $143(57.8)$ & 0.04 & 36.5 & 0.22 \\
\hline Yes & $282(53.3)$ & $139(49.2)$ & & 55.1 & \\
\hline \multicolumn{6}{|c|}{ Location of cattle ranches } \\
\hline Non-flooded area & $209(39.5)$ & $139(66.5)$ & 0.00 & 100 & 0.03 \\
\hline Flooded area & $320(60.4)$ & $143(44.6)$ & & 84.6 & \\
\hline \multicolumn{6}{|l|}{ Clinical signs } \\
\hline No & $499(94.3)$ & $271(54.3)$ & 0.06 & 46.6 & 0.18 \\
\hline Yes & $30(5.6)$ & $15(36.6)$ & & 24.3 & \\
\hline \multicolumn{6}{|l|}{ Positivity for EIA } \\
\hline No & $403(76.1)$ & $249(61.7)$ & 0.00 & 55.8 & 0.01 \\
\hline Yes & $126(23.8)$ & $33(26.1)$ & & 20.5 & \\
\hline \multicolumn{6}{|l|}{ Density } \\
\hline Up to $0.086 \mathrm{eq} / \mathrm{ha}$ & $97(18.3)$ & $61(62.9)$ & 0.03 & 55.7 & 0.30 \\
\hline Up to $0.086 \mathrm{eq} / \mathrm{ha}$ & $432(81.7)$ & $221(51.2)$ & & 43.7 & \\
\hline
\end{tabular}

* Values adjusted as the statistical weight of each ranch; ** Vaccination against diseases other than Equine Influenza.

Table 3

Results of the multiple linear regression model according to different variables evaluated and the prevalence of antibodies against EIV on ranches in Poconé, MT, Brazil

\begin{tabular}{lcc}
\hline $\begin{array}{l}\text { Multiple Linear } \\
\text { Regression Model }\end{array}$ & $Y=0.7050+0.1030 L-0.9577 D$ \\
\hline Variables & Estimate & $\boldsymbol{p}$ \\
\hline Intercept & 0.7050 & $<0.0001$ \\
Localization & 0.1030 & 0.0005 \\
Prevalence of EIAV & -0.9577 & 0.0001 \\
\hline
\end{tabular}

and exhibitions ${ }^{4}$. In addition, there is an intense trade and movement of equines in non-flooded areas in the municipality of Poconé, promoting circulation of the virus among ranches. These findings coincide with those reported by DIEL et al. ${ }^{8}$, who also observed that seropositive animals often participated in agricultural exhibition and practice of equine sport.

In contrast, ranches located in flooded areas showed the lowest rates of EIV seropositivity, including a negative correlation between EIAV prevalence and antibodies against EIV in herds. In other words, EIAV positive ranches had the lowest prevalence of EIV antibodies. According to Brazilian legislation for livestock, EIAV seropositive animals cannot be transported and are therefore forbidden from participating in agricultural exhibitions, public sales and sports practices, so the risk of infection by EIV is negligible.

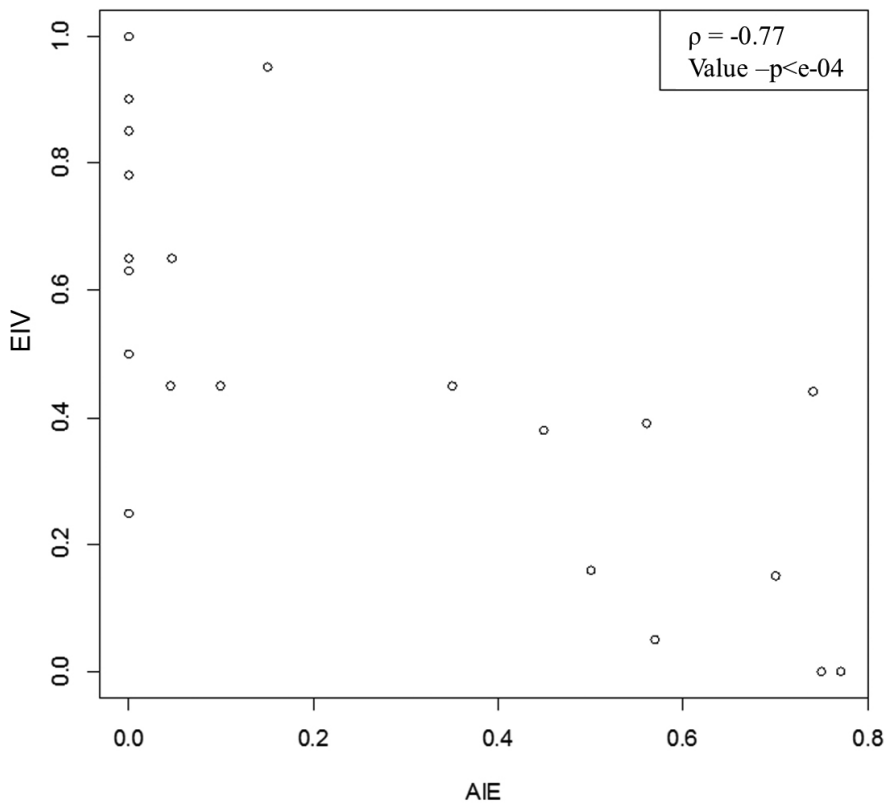

Fig. 2 - Negative correlation between the prevalence of EIAV and EIV on the cattle ranches surveyed in the municipality of Poconé, MT, Brazil.

Seropositivity was also associated with the absence of vaccination against encephalomyelitis, rabies and herpes virus in the surveyed herds. This indicates that ranches that adopt sanitary control measures had a lower prevalence of seropositive animals than the ones that do not adopt 
GAÍVA E SILVA, L.; BORGES, A.M.C.M.; VILLALOBOS, E.M.C.; LARA, M.C.C.S.H.; CUNHA, E.M.S.; OLIVEIRA, A.C.S.; BRAGA, I.A. \& AGUIAR, D.M. - Prevalence of antibodies against influenza virus in non-vaccinated equines from the Brazilian Pantanal. Rev. Inst. Med. Trop. Sao Paulo, 56(6): 487-92, 2014.

such measures. The absence of sanitary control measures leads to a higher proportion of seropositive equines.

As for clinical symptoms, equines without clinical signs presented a tendency $(p=0.06)$ for seropositivity. A positive serological result means past infection, and seroconversion of antibodies against EIV usually occurs during the convalescence period. At least two serological evaluations for the laboratory diagnosis of EIV are recommended, which is confirmed when the antibody titer shows a significant increase in the second evaluation ${ }^{11}$.

Equine males presented a higher tendency for infection $(p=0.10)$ than females. There are no records of sexual predisposition in EIV infection, and in the present study this observation may be related to the population size of males, since males are used for work on most ranches. As for species, horses showed a higher proportion of positivity than mules. However, after weighting by herd size, this result was not confirmed. It is important to state that the entire Equidae family is susceptible to infection by Influenza A virus ${ }^{11}$.

It was observed a high proportion of ranches in the municipality of Poconé with high prevalence of equines presenting antibodies against subtype H3N8 of Influenza A virus, indicating wide viral circulation and activity in the region. As the local characteristics of equine management were related to the presence of seropositive animals, specific sanitary controls against EIV should be adopted to prevent outbreaks that may compromise the local agribusiness.

\section{RESUMO}

\section{Prevalência de anticorpos contra o vírus da Influenza em equinos não vacinados do Pantanal Brasileiro}

A prevalência de anticorpos para o vírus da Influenza Equina (VIE) no município de Poconé, MT. foi determinada em 529 equídeos pela técnica de Inibição da hemaglutinação utilizando como antígeno a variante H3N8 (SP/1/85). A distribuição da positividade e possíveis associações entre os animais e as propriedades foram avaliadas pelo teste do Qui-quadrado e pelos modelos espacial autoregressivo misto e de regressão linear múltipla. A prevalência de anticorpos para o VIE no município de Poconé foi estimada em 45,2\% (IC 95\% 30,2 - 61,1\%) com títulos variando entre 20 e 1280 UIH. Das fazendas analisadas $23(92,0 \%)$ apresentaram animais soropositivos. Animais de fazendas não alagadas $(66,5 \%)$ e negativos para Anemia Infecciosa Equina (AIE) $(61,7 \%)$ foram associados a soropositividade. Não houve correlação espacial entre as fazendas estudadas, entretanto aquelas localizadas nas áreas não alagadas foram associadas à infecção. Observou-se correlação negativa entre a prevalência de anticorpos para o VIE e a presença de animais positivos para AIE nas propriedades. A elevada prevalência de anticorpos para o VIE detectada neste estudo sugere circulação viral ativa entre os animais, e as análises estatísticas indicam que o trânsito e aglomeração animal são fatores associados à transmissão do vírus na região.

\section{ACKNOWLEDGEMENTS}

The authors would like to thank CNPq (National Council for Scientific and Technological Development) for a scholarship granted to DM Aguiar, and CAPES (Federal Agency for the Support and Improvement of Higher
Education) for a scholarship granted to IA Braga. They are grateful to T. Bronhall and J. Daniels for their technical support.

\section{FUNDING}

This work was supported by the Research Support Foundation of the State of Mato Grosso FAPEMAT [446226/2009].

\section{REFERENCES}

1. Aguiar DM, Cavalcante GT, Lara MCCSH, Villalobos EMC, Cunha EMS, Okuda LH, et al. Prevalência de anticorpos contra agentes virais e bacterianos em eqüinos do município de Monte Negro, Rondônia, Amazônia Ocidental Brasileira. Braz J Vet Res Anim Sci. 2008;45:269-76.

2. Ariawan I, Frerichs RR. CSurvey: a cluster sampling utility program for Ibm compatible microcomputers. Version 1.5. Los Angeles. 1996. [cited 2011 Jun 25]. Available from: http://www.ph.ucla.edu/epi/csurvey.html

3. Bennett S, Woods T, Liyanage WM, Smith DL. A simplified general method for cluster - sample surveys of health in developing countries. World Health Stat Q. 1991;44:98-106.

4. Borges AMCM, Silva LG, Nogueira MF, Oliveira ACS, Segri NJ, Ferreira F, et al. Prevalence and risk factors for equine infectious anemia in Poconé municipality, northern Brazilian Pantanal. Res Vet Sci. 2013;9:76-81.

5. Câmara G, Carvalho MS, Cruz, OG, Correia V. Análise espacial de áreas. São José dos Campos: INPE; 2002. [cited 2010 Jan 30]. Available from: <http://www.dpi.inpe. br/gilberto/livro/analise/cap5-areas.pdf>

6. CNA. Confederação da Agricultura e Pecuária do Brasil. Estudo do complexo do agronegócio cavalo no Brasil. Brasília: Confederação da Agricultura e Pecuária do Brasil; 2006. MAPA Coletânea Estudos Gleba 40. [cited 2009 Jul 25]. Available from: <http://cepea.esalq.usp.br/pdf/cavalo_resumo.pdf>

7. Cunha EMS, Villalobos EMC, Nassar AFC, Lara MCCSH, Peres NF, Palazzo JPC, et al. Prevalência de anticorpos contra agentes virais em equídeos no sul do estado de São Paulo. Arq Inst Biol. 2009;76:165-71.

8. Diel DG, Almeida SR, Weiblen R, Frandoloso R, Anziliero D, Kreutz LC, et al. Prevalência de anticorpos contra os vírus da influenza, da arterite viral e herpesvírus em eqüinos do Estado do Rio Grande do Sul, Brasil. Cienc Rural. 2006;36:1467-73.

9. Heinemann MB, Cortez A, Lara MCCSH, Cunha EMS, Nassar AFC, Villalobos EMC, et al. Soroprevalência do vírus da influenza equina no Município de Uruará, PA, Brasil, Amazônia Oriental. Arq Inst Biol. 2009;76:697-9.

10. Instituto Brasileiro de Geografia e Estatística. Banco de dados: Cidade@. IBGE; 2009. [cited 2011 Dez 01]. Available from:< http://cod.ibge.gov.br/LFL >

11. Landolt GA, Townsend HGG, Lunn DP. Equine influenza infection. In: Sellon DC, Long MT, editors. Equine infectious diseases. Philadelphia: Saunders Elsevier; 2007. p. $124-34$.

12. World Organization for Animal Health. Serologic diagnosis of influenza virus infections by hemagglutination inhibition. In: WHO Manual on Animal Influenza Diagnosis and Surveillance. WHO; 2002. [cited 2012 Jan 01]. Available from: $<$ http://www.who.int/vaccine_research/diseases/influenza/WHO_manual_on_animaldiagnosis_and_surveillance_2002_5.pdf>

13. Oliveira GS, Schiavo PA, Mazur C, Andrade CM. Prevalência de anticorpos para o vírus da influenza eqüina, subtipo H3N8, em equídeos apreendidos no Estado do Rio de Janeiro. Cienc Rural. 2005;35:1213-5.

14. Otte MJ, Gumm ID. Intra-cluster correlation coefficient of 20 infections calculated from the results of cluster-sample surveys. Prev Vet Med. 1997;31:147-50. 
GAÍlVA E SILVA, L.; BORGES, A.M.C.M.; VILLALOBOS, E.M.C.; LARA, M.C.C.S.H.; CUNHA, E.M.S.; OLIVEIRA, A.C.S.; BRAGA, I.A. \& AGUIAR, D.M. - Prevalence of antibodies against influenza virus in non-vaccinated equines from the Brazilian Pantanal. Rev. Inst. Med. Trop. Sao Paulo, 56(6): 487-92, 2014.

15. Pena LJ, Pena DA, Barrios PR, Dale R, Lamêgo MRA, Moraes MP. Levantamento soro-epidemiológico da infecção pelo vírus da anemia infecciosa eqüina, da influenza eqüina-2 e do herpesvírus eqüino-1 em rebanhos do sul do Estado do Pará, Brasil. Braz J Vet Res Anim Sci. 2006;43:537-42.

16. Santos SA, Sereno JRB, Mazza MCM, Mazza CA. Origin of the Pantaneiro horse in Brazil. Arch Zootecnia. 1992;41:371-81.

18. Timoney PJ. Equine Influenza. Comp Immunol Microbiol Infect Dis. 1996;19:205-11.

19. Waghmare SP, Mode SG, Kolte AY, Babhulkar N, Vyavahare SH, Patel A. Equine influenza: an overview. Vet World. 2010;3:194-7.

Received: 17 January 2014

Accepted: 20 March 2014

17. Silva RAMS, Dávila AMR, Iversson LB, Abreu UGP. Equine viral diseases in the Pantanal, Brazil. Studies carried out from 1990 to 1995. Rev D'Elevage Med Vet Pays Trop. 1999;52:9-12. 